\title{
NA TEORIA E NA FICÇÃO: A VANGUARDA EM CLARICE LISPECTOR
}

\section{IN THEORY AND FICTION: THE VANGUARD IN CLARICE LISPECTOR}

\author{
Marília Gabriela Malavolta Pinho* \\ Universidade Estadual Paulista Júlio de Mesquita Filho

\section{Luiz Gonzaga Marchezan ${ }^{* *}$ \\ Universidade Estadual Paulista Júlio de Mesquita Filho}

RESUMO: O conto "Os desastres de Sofia" (1964), de Clarice Lispector, pode ser lido como metáfora ficcional da maneira como a escritora elaborou e apresentou o conceito de "Vanguarda". Reflexões filosóficas de Walter Benjamin (1933) contêm os argumentos que Clarice, no enredo desse conto, revigora, trazendo em chaves modernas, vanguardistas, segundo sua concepção, o que Benjamin sancionou pelo olhar melancólico do passado. Assim, Clarice se faz notar como escritora de uma prosa (poética) conscientemente filiada à tradição da poesia brasileira moderna.

PALAVRAS-CHAVE: Clarice Lispector. Walter Benjamin. Vanguarda. Modernismo. Modernidade.

\footnotetext{
* Possui mestrado em Teoria e História Literária pela Unicamp (2006) e graduação em Letras pela Unicamp (2001). Doutoranda em Estudos Literários pela Universidade Estadual Paulista Júlio de Mesquita Filho (UNESP/ FCLAR). Araraquara, São Paulo, Brasil. E-mail: mgmalavolta@gmail.com ** Doutor pela Universidade de São Paulo (USP) e Mestre pela Universidade Estadual Paulista Júlio de Mesquita Filho (UNESP). Docente da Faculdade de Ciências e Letras (UNESP/FCLAR). Araraquara, São Paulo, Brasil. E-mail: zmarchezan@fclar.unesp.br
} 
ABSTRACT: The short story "Os desastres de Sofia” (1964), of Clarice Lispector, can be read as fictional metaphor for the way as the writer elaborated and presented the concept of "Vanguard". Philosophical reflections of Walter Benjamin (1933) contains the arguments that Clarice, in this narrative, invigorates, by the use of modern keys, vanguardist, according to her conception, which Benjamin sanctioned by the melancholic look of the past. Clarice is notable as a writer of prose affiliated with the brazilian modern poetry.

KEYWORDS: Clarice Lispector. Walter Benjamin. Vanguard. Modernism. Modernity. 


\section{"SOBRE O CONCEITO DE VANGUARDA", UMA INTRODUÇÃO}

Enquanto o conceito de "Vanguarda", em arte, é imediatamente associado à mudança na forma, Clarice Lispector questionou a frequente dissociação forma versus conteúdo. Empenhada em pensar com mais pormenores o conceito, identificou-o, essencialmente, como sendo um novo modo de apreensão do mundo e de compreensão de si mesmo que leva, então, a uma mudança formal. O texto no qual há essa definição é uma espécie de ensaio, intitulado "Sobre o conceito de vanguarda", que Clarice produziu para ler em conferências das quais participou no Brasil e nos EUA, de 1963 a 1974. Conforme informação de Teresa Montero e Lícia Manzo, em 63

Clarice Lispector foi convidada a proferir uma palestra sobre a vanguarda na literatura brasileira, no XI Congresso Bienal do Instituto Internacional de Literatura Ibero-Americana, realizado de 29 a 31 de agosto, na Universidade do Texas.

(LISPECTOR , 2005, p. 93) 
Muito bem recebido fora e dentro do Brasil, o mesmo conteúdo produzido para essa palestra foi lido também, com ligeiras modificações, em outros lugares por onde Clarice discorreu, a convite, sobre literatura, a saber: Vitória, Belo Horizonte, Campos, Belém do Pará e, por último, Brasília, já em 2 de junho de 1974. Seus originais encontram-se na Fundação Casa Rui Barbosa, junto ao acervo da escritora. Ao final do texto, que não está especificamente datado em conformidade com suas localidades, a autora reúne as seguintes indicações: "Texas - Brasília - Vitória do Espírito Santo - Belo Horizonte - Campos - (71) Belém do Pará". No início, feita a introdução de sua participação, Clarice anuncia assim o seu objeto:

Não pude deixar de usar essa oportunidade de escrever um [esse] breve [e superficial] relato, somente para ter uma experiência pessoal que me faltava, além de todas as outras. O que espero não chegará a prejudicar a conferência propriamente dita. Nada impede, suponho, que esta pequena tentativa de exposição me dê proveito e gosto: pelo menos alguém terá que se beneficiar. Talvez o que estarei [estou] fazendo neste relato [palestra] é [seja] o que se chama de 'abrir uma porta aberta'. Só que para mim era fechada. Nessa minha experiência fui de início levada a pensar - pela primeira vez com atenção - na palavra 'vanguarda"'.

(LISPECTOR, 1992, p. 120)

Em sua exposição, a autora coloca a tônica da escrita de vanguarda primeiramente nos alcances internos de um "eu” (maturações nos seus modos de ver, ser, sentir), depois nos seus escritos produzidos; primeiro dentro, depois fora. Anunciando colocar de lado a palavra "vanguarda" no seu sentido europeu, pretensamente universal, de revolução das formas de expressão, Clarice discorre sobre o caráter vanguardista da geração de 1922 a partir do que reconhece, justamente, como sendo um "novo modo de ser" brasileiro: 
O movimento de 1922 foi movimento de profunda libertação, libertação significa sobretudo um novo modo de ver, libertação é sempre vanguarda, e também nessa de 1922 quem estava na linha de frente se sacrificou. Mas libertação é às vezes avanço apenas para quem se está libertando, e pode não ter valor de moeda corrente para os outros. Para nós, 1922 significou vanguarda, por exemplo, independente de qualquer valor universal. Foi movimento de posse: movimento de tomada de nosso modo de ser, de um dos nossos modos de ser, o mais urgente naquela época talvez (LISPECTOR, 1992, p. 121).

Mais adiante, a autora sintetiza:

[...] a vanguarda de forma modifica o conceito das coisas, mas há o outro modo de vanguarda, que é uma maneira de ver que vai lenta e necessariamente transformando a forma.

(LISPECTOR, 1992, p. 123).

Antecipando o que abordará mais ao final do texto, a saber, o legado do movimento de 22, convoca à linha de frente da Literatura jovens escritores de seu próprio período, e associa uma nova vanguarda a um trabalho ainda mais minucioso com a língua portuguesa do Brasil:

[...] a atmosfera é de vanguarda, o nosso crescimento íntimo está forçando as comportas e rebentará com as formas inúteis de ser ou de escrever. Estou chamando o nosso progressivo auto-conhecimento de vanguarda. Estou chamando de vanguarda 'pensarmos' a nossa língua. Nossa língua ainda não foi profundamente trabalhada pelo pensamento. 'Pensar a língua portuguesa do Brasil significa pensar sociologicamente, [psicologi- 
camente,] filosoficamente, linguisticamente sobre nós mesmos. Os resultados são e serão o que se chama de língua [gem] literária, isto é, língua [gem] que reflete e diz, com palavras que instantaneamente aludem a coisas que vivemos; numa linguagem real; numa linguagem que é fundo-forma, a palavra é na verdade um ideograma.

(LISPECTOR, 1992, p. 123)

Esse apurado trabalho com a palavra oriunda das "coisas que vivemos" tem franca filiação com o que, décadas anteriores, Mário de Andrade observava acerca do novo trabalho do poeta e do seu leitor. Aludindo à ação de um subconsciente, é deste que, segundo o escritor, o poeta recebe suas palavras telegramáticas. E não, em rechaço aos românticos, do alto de uma "torre de marfim", mas sim "no bonde, quando o pobre vai para a repartição, para a Faculdade de Filosofia, para o cinema." Caberá ao leitor buscar os sentidos desse tipo de produção:

"Assim virgem" - prossegue Mário de Andrade - "sintético, enérgico, o telegrama dá-lhe fortes comoções, exaltações divinatórias, sublimações, poesia. Reproduzi-las!... E o poeta lança a palavra solta no papel. É o leitor que se deve elevar à sensibilidade do poeta não é o poeta que se deve baixar à sensibilidade do leitor. Pois este que traduza o telegrama!".

(ANDRADE, 2010, p. 18)

A personagem Ana, do conto “Amor", de Laços de família, de 1960, dá início a um forte processo de auto-descoberta, passível de ressignificar sua vida de mulher-dona-de-casa, no interior de um bonde, quando, cena trivial, dele vê um cego mascando chiclete em um ponto de ônibus. Como outra evidência da referida filiação, alude-se aqui à importância do papel do leitor na obra de Clarice Lispector, não só em virtude das exigências de narrativas por vezes tidas como cifradas e enigmáticas - telegramas à 
espera de tradução? - como também pelo destaque ao leitor dado explicitamente pela própria autora, conforme se vê na dedicatória de A paixão segundo $G H$ (1964):

\begin{abstract}
A possíveis leitores
Este livro é como um livro qualquer. Mas eu ficaria contente se fosse lido apenas por pessoas de alma já formada. Aquelas que sabem que a aproximação do que quer que seja, se faz gradualmente e penosamente - atravessando inclusive o oposto daquilo que se vai aproximar. Aquelas pessoas que, só elas, entenderão bem devagar que este livro nada tira de ninguém. A mim, por exemplo, a personagem $\mathrm{G}$. H. foi dando pouco a pouco uma alegria difícil; mas chama-se alegria. C.L.
\end{abstract}

(LISPECTOR, 1998)

Nesse romance o leitor é ainda alçado à condição de verdadeiro personagem, na medida em que ao longo de toda a narrativa uma narradora auto-diegética pede-lhe que segure sua mão, como condição do próprio prosseguimento da sua narração.

Não obstante essas correlações sejam notórias, a filiação mais efetiva que se pode evidenciar entre as aspirações de Mário de Andrade (para a poesia) e as de Clarice Lispector (para a prosa) reside mesmo no empenho da autora em fazer girar a roda da vanguarda, em dar o seu feitio à literatura brasileira, em, na esteira dos anseios poéticos da geração de 22, identificar e buscar realizar aquilo de que a literatura brasileira precisava ou poderia ser naquele momento. É nesse sentido que a conclusiva afirmação da escritora sobre uma linguagem literária, fruto de se pensar a língua portuguesa do Brasil, "que reflete e diz, com palavras que instantaneamente aludem a coisas que vivemos; numa linguagem real; numa linguagem que é fundo-forma”, merece destaque não só pela herança modernista da valorização da trivial cena cotidiana mas também pela busca do caráter da nova expressão literária que deverá aludir ao que vivemos sem disto se dissociar; que deverá, antes, buscar o essencial das cenas mais triviais ou aquilo que, 
a partir delas, pode bruscamente irromper em forma de íntima, e por vezes indizível, compreensão. A palavra, como tantas vezes enunciou a escritora, é o instrumento dessas buscas. Usá-la como tal exige, antes, que seu agente "trabalhe a si próprio":

"É maravilhosamente difícil escrever em língua que ainda borbulha, que precisa mais do presente do que mesmo de uma tradição. Em língua que para ser trabalhada, exige que o escritor se trabalhe a si próprio como pessoa. Cada sintaxe nova é então reflexo indireto de novos relacionamentos, de um maior aprofundamento em nós mesmos, de uma consciência mais nítida do mundo e do nosso mundo. Cada sintaxe nova abre então pequenas liberdades. Não as liberdades arbitrárias de quem pretende variar, mas uma liberdade mais verdadeira e esta consiste em descobrir que se é livre. Isto não é fácil. Descobrir que se é livre é uma violentação criativa. Nesta se ferem escritor e língua. Qualquer aprofundamento é penoso. Ferem-se mas reagem vivos".

(LISPECTOR, 1992, p. 123)

Com base precisamente nesse trecho acima é que o crítico português Carlos Mendes Sousa, em análise do texto-conferência, inscreve no signo do "movimento" a perspectiva então apresentada por Clarice; movimento tanto de ação e reação entre pensamento e língua quanto de incessante busca, de constante trabalho estético (e interno) aí implicado. Neste caso, a autora estaria incorporando, segundo Sousa, um dos princípios do Movimento Modernista postos como fundamentais por Mário de Andrade em sua conferência no Itamaraty, de 1942.

Há uma mutação lenta, quase imperceptível, e interior. Mostra-se de facto aqui uma tese - um ponto de vista claramente definido: posto o pensamento em movimento ele vai mover a língua e, ao mesmo tempo, ver- 
-se-á por ela movido. As implicações maiores serão visíveis no plano da sintaxe. Mas tudo terá que vir de dentro e nunca de modelagens à superfície, nunca de arranjos de maquilhagem, de variações de qualquer tipo de modelagem. É esse o modo como Clarice incorpora muito rigorosamente a lição de Mário de Andrade quando este proclamava o 'direito permanente à pesquisa estética.

(SOUSA, 2002)

Em reforço a essa ressalva de Sousa, convém ainda conjugar a perspectiva de Clarice acerca dessa genuína escrita que vem de dentro ao que em 1924 asseverou Mário de Andrade sobre a poesia: "o movimento lírico nasce no eu profundo" (ANDRADE, 2010, p. 17).

Para Clarice Lispector, enfim, sendo vanguarda preliminarmente um modo de ver, ser, apreender, a si mesmo e as coisas ao redor, é-lhe intrínseco um movimento, uma modificação progressiva natural (implicada na modificação, no amadurecimento, de um "eu") que tem como base matricial a geração de 22:

Que tenhamos inclusive ultrapassado 1922, ainda mais o reafirma como movimento de vanguarda: foi tão absorvido e incorporado que se superou, o que é característica de vanguarda, e se a 1922 nos referimos historicamente, na realidade ainda somos resultado dele. O próprio Mário de Andrade, se ainda vivesse, teria incorporado a si próprio, ainda mais, o melhor de sua sadia rebelião, e seria hoje um clássico [de] si mesmo. O futuro de um homem de vanguarda é amanhã não ser lido exatamente por aqueles que mais se assemelham a ele: exatamente os mais aptos a entender sua necessidade de procura estarão amanhã ocupados demais com novos movimentos de procura. Pensando em vários homens de nossa vanguarda, ocorreu-me 
sem nenhuma melancolia que é então, exatamente, que o escritor de vanguarda terá atingido sua finalidade maior: se terá dado tanto e terá sido tão bem usado, que amanhã desaparecerá. Eu disse amanhã. Mas depois-de-amanhã - passada a vanguarda, passado o necessário silêncio - depois de amanhã ele se levanta de novo. É claro que Mário de Andrade não desapareceu: 1922 não foi ontem, foi ante-ontem".

(LISPECTOR, 1992, p. 123)

Salientando que a tomada de realidade com a qual identifica o conceito de vanguarda nada tem a ver com ufanismo, mas sim com auto-conhecimento, Clarice coloca em sequência referências a versos de Gonçalves Dias, Carlos Drummond de Andrade e Manuel Bandeira de modo a exemplificar o movimento evolutivo desse processo de auto-conhecimento, de maturação, e o faz reforçando a importância do legado da geração de 22 .

A nossa evidente tendência nacionalista não provém de nenhuma vontade de isolamento: é movimento sobretudo de auto-conhecimento, legítimo assim como qualquer movimento de arte é movimento de conhecimento, não importa se de consequências nacionais ou internacionais. 'Nossas várzeas têm mais flores' - e este é um verso da 'Canção do Exílio', o poema mais conhecido de Gonçalves Dias, figura importante do movimento romântico brasileiro - cedeu lugar à procura muito mais grave de constatações, a uma procura muito mais bela de nós mesmos porque é feita com esforços, rejeições, dor, espantos e alegrias da visão. Estamos muito mais realistas agora, no sentido em que estamos muito mais artistas. Hoje diríamos: nossas várzeas têm [ainda] flores. Quem escreve e quem vive, sabe que isto não é fácil nem simples. Hoje inclusive nós sofremos as nossas flores. Tudo isso para mim 
é vanguarda, ou, muito mais, é atmosfera de vanguarda: pois é assim que estou chamando o nosso crescimento, e assim estou chamando a nossa maturação.

Foi, por exemplo, em consequência dessa vanguarda geral que recebemos com o coração aberto a aparente secura de Carlos Drummond de Andrade. E este homem, tenho certeza, tocaria qualquer pessoa que cresce, e em qualquer parte onde essa pessoa viva. Falei em aparente secura e de como o recebemos tão fundamente assim como se recebe uma seta seca e pura. É mais um indício de como há muito passamos da fase exclamatória e do modo apenas deslumbrado de tomar contato com a nossa vida. Mas os excessos de 1922, nesse sentido, foram inclusive absolutamente necessários para quebrar o pudor literário do amor que hoje é sobretudo visão e exigência. $\mathrm{O}$ abrasileiramento ostensivo e corajoso de Mário de Andrade em Macunaíma, nos contos, e menor nos poemas, no que diz respeito à linguagem, cedeu lugar à intimidade familiar que Manuel Bandeira teve em relação a um jeito que já tínhamos e que não usávamos em literatura - uma ternura irônica pelo sentimentalismo, mas felizmente sem deixar de usufruir dele todo.

(LISPECTOR, 1992, p. 124)

Tendo por base a definição de vanguarda feita pela escritora e citando o crítico Antonio Candido, Carlos Mendes Sousa assim destaca a vanguardista que foi Clarice:

Antonio Candido, após chamar a atenção para algumas influências decisivas no quadro heterogéneo da narrativa dos anos 60 e 70 ('o impacto do boom jornalístico moderno, do espantoso incremento de revistas e pequenos semanários, da propaganda, da televisão, das 
vanguardas poéticas que atuam desde o final dos anos 50 , sobretudo o concretismo, storm-center que abalou hábitos mentais, inclusive porque se apoiou em reflexão teórica exigente'), lembra que antes disso se destaca, embora brandamente, o nome de Clarice Lispector: 'Ela é provavelmente a origem das tendências desestruturantes, que dissolvem o enredo na descrição e praticam esta com o gosto pelos contornos fugidios'. É esse lugar que aqui queremos relembrar: o da voz antecipadora que foi a de Clarice. Quer em relação a uma configuração que terá tido grande ressonância em diversas escritas, com uma prática literária próxima do nouveau roman - e Antonio Candido não deixou de o assinalar - quer como antecipadora das tendências pós-modernas da ficção dos anos 80 e 90.

(SOUZA, 2002)

A voz antecipadora de Clarice Lispector - perspectiva reforçada por este artigo - é, então, a de uma pessoa-escritora com olhar mirando adiante, à frente, às novas e urgentes possibilidades de ser e de escrever. Este seu traço, claramente pronunciado pela própria Clarice pela primeira vez em 1963, viabiliza, assim, uma leitura essencialmente moderna e vanguardista de um conto seu de 1964, "Os desastres de Sofia".

Especificamente, o presente artigo objetiva argumentar que esse conto de 1964 metaforiza, nas complexidades do seu enredo, o que Clarice Lispector pronunciou um ano antes acerca do conceito de vanguarda.

$\mathrm{O}$ enredo do conto, segundo a análise aqui proposta, reconfigura, em partes, as abordagens de Walter Benjamin presentes em "O Narrador" e em "Experiência e Pobreza" sancionadas por um melancólico olhar voltado para trás. Enquanto Benjamin dá praticamente como extinta a transmissão oral da experiência, dos conselhos, Clarice, no citado conto, reorganiza e revigora essa transmissão, metaforizando nas peripécias de uma menina - a protagonista Sofia - o trabalho, "vanguardista", de auto-descoberta que é intrínseco ao ofício do escritor tal qual Lispector o compreendeu. 
Conforme se mostrará logo adiante, partindo, ambos, exatamente de uma mesma fábula que traz, como moral burguesa, a premência do trabalho, Clarice (na ficção) e Benjamin (no ensaio filosófico) miram horizontes distintos. O de Benjamin, na esteira da modernidade baudelaireana, é marcado pela melancolia do fim de um período; o de Clarice, na esteira do modernismo brasileiro, é marcado pelo inocente olhar da infância, no que tem de promessa do novo; o de Clarice, na esteira da sua própria compreensão de vanguarda, é marcado pelo processo da auto-descoberta de uma menina, o que é revisitado pela memória dela adulta que, assim, matura-se ainda mais, enquanto mulher e escritora.

\section{1. “OS DESASTRES DE SOFIA” E A MODERNIDADE SEGUNDO WALTER BENJAMIN: EXPERIÊNCIA VERSUS INOCÊNCIA; POBREZA VERSUS RIQUEZA}

O conto "Os desastres de Sofia", história de abertura de A Legião Estrangeira (1964), de Clarice Lispector, tematiza a gênese da escritura. Apresenta-nos o desabrochar, na menina Sofia, do olhar e da mão de escritora, bem como a intrínseca perplexidade frente à tarefa que lhe passa a caber. Na urdidura do conto, a gênese desse processo correspondente à escrita está, por sua vez, conforme análise aqui proposta, entrelaçada à tradição da narrativa oral.

Walter Benjamin (2011), em sua crítica à reprodutibilidade técnica das histórias, no período identificado por ele como Modernidade (final do século XIX e início do XX), destaca o empobrecimento da transmissão oral da narrativa diante do advento do romance na condição de produto e diante do seu aspecto segregador: na origem do romance e na sua leitura estaria o indivíduo isolado, impossibilitado de receber e de dar conselhos. ${ }^{1}$ No moderno conto de Clarice, a tradição da narrativa oral é de algum modo preservada em sua essência no instante mesmo em que compõe o enredo de um texto escrito, de um conto literário.

1 Em "Experiência e Pobreza", o eixo central do empobrecimento abordado por Benjamin é a experiência da guerra, que responderia por um modo de narrar absolutamente empobrecido em experiências comunicáveis. 
Análises do referido conto somadas a apontamentos de Walter Benjamin sobre o Narrador e a Modernidade serão, na sequência, apresentados de modo a se evidenciar os aspectos propostos.

\subsection{0 conto}

Em “Os desastres de Sofia”, Sofia, a narradora auto-diegética já adulta, narra o modo desafiador como, menina, lidava com seu professor do curso primário; antes, o modo intenso como o percebia e o sentia:

O professor era gordo, grande e silencioso, de ombros contraídos. Em vez de nó na garganta, tinha ombros contraídos. Usava paletó curto demais, óculos sem aro, com um fio de ouro encimando o nariz grosso e romano. E eu era atraída por ele. Não amor, mas atraída pelo seu silêncio e pela controlada impaciência que ele tinha em nos ensinar e que, ofendida, eu adivinhara. Passei a me comportar mal na sala. Falava muito alto, mexia com os colegas, interrompia a lição com piadinhas, até que ele dizia, vermelho:

- Cale-se ou expulso a senhora da sala.

Ferida, triunfante, eu respondia em desafio: pode me mandar! Ele não mandava, senão estaria me obedecendo. (LISPECTOR, 1999, p. 11)

Ele me irritava. De noite, antes de dormir, ele me irritava. Eu tinha nove anos e pouco, dura idade como o talo não quebrado de uma begônia. Eu o espicaçava, e ao conseguir exacerbá-lo sentia na boca, em glória de martírio, a acidez insuportável da begônia quando é esmagada entre os dentes; e roía as unhas, exultante. De manhã, ao atravessar os portões da escola, pura como ia com meu café com leite e a cara lavada, era um choque deparar em carne e osso com o homem que me 
fizera devanear por um abismal minuto antes de dormir. [...] De manhã - como se eu não tivesse contado com a existência real daquele que desencadeara meus negros sonhos de amor - de manhã, diante do homem grande com seu paletó curto, em choque eu era jogada na vergonha, na perplexidade e na assustadora esperança. A esperança era o meu pecado maior.

(LISPECTOR, 1999, p. 12)

A despeito dos enfrentamentos cotidianos, o grande conflito entre ambos se dá quando da escrita de uma história cujo tema fora proposto pelo professor. No que concerne à trama do conto, o resultado desse conflito é a percepção assustada, por parte da menina, da sua escrita como iniciação a um sacro ofício. A proposta do professor nos é apresentada em discurso direto; em fala, portanto: "Vou contar uma história, disse ele, e vocês façam a composição. Mas usando as palavras de vocês. Quem for acabando não precisa esperar pela sineta, já pode ir para o recreio" (LISPECTOR, 1999, p. 16).

E o que ele efetivamente propusera é também falado; trata-se de uma narrativa contada aos alunos, conforme recupera explicitamente a narradora:

O que ele contou: um homem muito pobre sonhara que descobrira um tesouro e ficara muito rico; acordando, arrumara sua trouxa, saíra em busca do tesouro; andara o mundo inteiro e continuava sem achar o tesouro; cansado, voltara para sua pobre, pobre casinha; e como não tinha o que comer, começara a plantar no seu pobre quintal; tanto plantara, tanto colhera, tanto começara a vender que terminara ficando muito rico. (LISPECTOR, 1999, p. 16)

Em cumprimento da tarefa, Sofia escreve uma história avessa à moral presente na narrativa contada e, conforme declara, escreve-a de qualquer jeito, despretensiosamente, apenas para ser a primeira a correr ao recreio e demonstrar ao professor "rapidez", o que lhe parecia essencial para se viver e o 
que, "tinha certeza, o professor só podia admirar" (LISPECTOR, 1999, p. 17). Mais tarde, quando volta à sala para buscar qualquer coisa - e sem, antes, ter recebido qualquer elogio por sua velocidade -, é surpreendida pelo professor já leitor de sua composição, absolutamente surpreso, curioso e esperançoso daquilo que a menina escrevera. A moral avessa encantara o professor.

A história que eu transcrevera em minhas próprias palavras era igual a que ele contara. Só que naquela época eu estava começando a 'tirar a moral das histórias', o que, se me santificava, mais tarde ameaçaria sufocar-me em rigidez. Com alguma faceirice, pois, havia acrescentado as frases finais. Frases que horas depois eu lia e relia para ver o que nelas haveria de tão poderoso a ponto de enfim ter provocado o homem de um modo como eu própria não conseguira até então. Provavelmente o que o professor quisera deixar implícito na sua história triste é que o trabalho árduo era o único modo de se chegar a ter fortuna. Mas levianamente eu concluíra pela moral oposta: alguma coisa sobre o tesouro que se disfarça, que está onde menos se espera, que é só descobrir, acho que falei em sujos quintais com tesouros. Já não me lembro, não sei se foi exatamente isso. Não consigo imaginar com que palavras de criança teria eu exposto um pensamento simples mas que se torna complicado. Suponho que, arbitrariamente contrariando o sentido real da história, eu de algum modo já me prometia por escrito que o ócio, mais que o trabalho, me daria as grandes recompensas gratuitas, as únicas a que eu aspirava. [...] Ao contrário do trabalhador da história, na composição eu sacudia dos ombros todos os deveres e dela saía livre e pobre, e com um tesouro na mão.

(LISPECTOR, 1999, p. 18) 
O efeito imediato de tal história, assim que lida pelo professor, representou um desmoronamento no modo como Sofia lidava com ele e com o mundo:

A súbita falta de raiva nele. Olhei-o intrigada, de viés. E aos poucos desconfiadíssima. Sua falta de raiva começara a me amedrontar, tinha ameaças novas que eu não compreendia. [...] Perplexa, e a troco de nada, eu perdia o meu inimigo e sustento.

(LISPECTOR, 1999, p. 21)

O professor, então, gostara muito da história, mais do que isso, confiara na menina (LISPECTOR, 1999, p. 23). O encantamento e a confiança vistos por Sofia envergonham-na e decepcionam-na: "Ele matava em mim, pela primeira vez a minha fé nos adultos: também ele, um homem, acreditava como eu nas grandes mentiras" (LISPECTOR, 1999, p. 24).

Assim, Sofia volta correndo, "horrorizada" e "espantada", para o parque do colégio, onde busca entender um pouco mais o que se passara, embora ainda houvesse "muito mais corrida" dentro de si. Reconhece ter sido "tudo o que aquele homem tivera naquele momento" (LISPECTOR, 1999, p. 25).

Pelo menos uma vez ele teria que amar, e sem ser a ninguém - através de alguém. E só eu estivera ali. Se bem que esta fosse a sua única vantagem: tendo apenas a mim, e obrigado a iniciar-se amando o ruim, ele começara pelo que poucos chegavam a alcançar. [...] Ali estava eu, a menina esperta demais, e eis que tudo o que em mim não prestava servia a Deus e aos homens. Tudo o que em mim não prestava era o meu tesouro. Como uma virgem anunciada, sim. Por ele me ter permitido que eu o fizesse enfim sorrir, por isso ele me anunciara. Ele acabava de me transformar em mais do que o rei da Criação: fizera de mim a mulher do rei da Criação. (LISPECTOR, 1999, p. 26) 
O que a narradora nos coloca, enfim, é que a continuação escrita que ela dera à história contada pelo professor acabou por transformá-la em escritora; passa a lhe caber o ofício sagrado da criação. Com efeito, ela adulta (e, portanto, já escritora), ao recuperar essas memórias de menina, sugere-nos a origem não só dessa história como também de outras: "Foi talvez por tudo o que contei, misturado e em conjunto, que escrevi a composição que o professor mandou, ponto de desenlace dessa história e começo_de outras (...)" (LISPECTOR, 1999, p. 16).

\subsection{0 conto diante de "Experiência e Pobreza" e de "O Narrador"}

A narrativa contada pelo professor de Sofia é essencialmente aquela apresentada por Benjamin no início de "Experiência e Pobreza", como exemplo daquilo que se perdia na Modernidade. As pequenas diferenças ficam por conta dos rearranjos característicos da transmissão oral que a caracteriza, justamente.

Em nossos livros de leitura havia a parábola de um velho que no momento da morte revela a seus filhos a existência de um tesouro enterrado em seus vinhedos. Os filhos cavam, mas não descobrem qualquer vestígio de tesouro. Com a chegada do outono, as vinhas produzem mais do que qualquer outra na região. Só então compreenderam que o pai lhes havia transmitido uma certa experiência: a felicidade não está no ouro, mas no trabalho".

(BENJAMIN, 2011, p. 114)

Benjamin segue apontando que narrativas dessa natureza eram apresentadas aos jovens na medida em que cresciam, com a finalidade de lhes transmitir experiência. A apresentação / transmissão podia ser, segundo ele: "[...] de forma concisa, com a autoridade da velhice, em provérbios; de forma prolixa, com a sua loquacidade, em histórias; muitas vezes como narrativa de países longínquos, diante da lareira, contada a pais e netos" (BENJAMIN, 2011, p. 114). 
Constatando o fim dessas transmissões, que se deveria a uma geração pós primeira guerra mundial absolutamente empobrecida em experiências comunicáveis e mais a um "monstruoso desenvolvimento da técnica sobrepondo-se ao homem”, Benjamin interroga:

Que foi feito de tudo isso? Quem encontra ainda pessoas que saibam contar histórias como elas devem ser contadas? (...) Quem é ajudado, hoje, por um provérbio oportuno? Quem tentará, sequer, lidar com a juventude invocando sua experiência?

(BENJAMIN, 2011, p. 114)

Na urdidura do conto de Clarice, encontram-se elementos (narrativos) que parecem funcionar como respostas ou antirrespostas a essas questões. No conto publicado em 1964, uma típica narrativa oral contada é a gênese de tantas outras histórias escritas; um adulto é ajudado por uma história oportuna escrita por uma jovem que, assim, é também ajudada na percepção precoce de um grandioso ofício.

Talvez daí surgisse a simplificada questão: a dupla "transmissão oral e adultos" cede espaço à outra dupla "transmissão escrita e jovens"? Isto porque, em "O Narrador", ao abordar o traço utilitário das narrativas orais, Benjamin as associa a uma transmissão que parte do adulto em direção ao mais jovem e que encontra seu grande valor ao resultar em conselho não propriamente dado mas sequenciado no interior da própria narrativa, o que de fato seria melhor realizado pelo adulto experiente, vivido ${ }^{2}$. Sugeriu-se mais acima "simplificada questão" porque, partindo-se dessas acepções benjaminianas em direção ao conto de Clarice, o que se encontra é uma nova combinação, intensamente tramada na narrativa, entre esses elementos, e não qualquer resposta direta, simplificadora.

Sofia, a jovem menina que continua a história contada pelo professor, é quem o aconselha. A descrição do professor, no conto, evidencia uma sua

\footnotetext{
2 “o narrador é um homem que sabe dar conselhos", e sabe que "aconselhar é menos responder a uma pergunta que fazer uma sugestão sobre a continuidade de uma história que está sendo narrada" (BENJAMIN, 2011, p. 200).
} 
precariedade de experiências em virtude de uma precariedade de existência, de uma angústia, percebidas pela menina, em toda sua inocência. Assim, é a menina, ainda não plenamente tecida em sua própria existência e, portanto, experiência, quem encarna outra forma de sabedoria - a inocência - a partir da qual, inadvertidamente, aconselha o professor. A menina Sofia encarna, também, o que Benjamin aponta ter acabado, a distensão temporal, o ócio, associados às atividades manuais e completamente estranhos ao momento de premência urbana e industrial ao qual se reporta. Se Sofia ainda não contava com a experiência dos anos vividos, reconhece, acerca de si mesma, a premência do valor ao ócio, à liberdade e à pobreza, que efetivamente a deixariam "com um tesouro na mão", conforme ela mesma diz: "Ao contrário do trabalhador da história, na composição eu sacudia dos ombros todos os deveres e dela saía livre e pobre, e com um tesouro na mão" (LISPECTOR, 1999, p. 18).

Este "tesouro na mão" da ficção de Clarice é o que diverge da "pobreza" salientada por Benjamin, enquanto é o que converge com a riqueza da palavra solta do poeta moderno, abordada por Mário de Andrade, com referência final a versos de Rimbaud:

[...] o poeta reintegrado assim na vida recebe a palavra solta. A palavra solta é fecundante, evocadora... Associação de imagens. Telegrama: 'Espada vitoriosa de Horácio'. Associação: 'Antena de telegrafia sem fio’. Telegrama: 'fios telefônicos, elétricos constringindo a cidade.' Associação: 'dedos de Otelo no colo de Dêsdemona'. Os Horácios + Otelo $=2$ assuntos. Os Horácios + Otelo + Antena radiográfica + Fios elétricos $=4$ assuntos. Resultado: riqueza, fartura, pletora. Por isso Rimbaud, precursor, exclamava:

Je suis Mille fois plus riche!

Sem ter um franco no bolso virgem.

(ANDRADE, 2010, p. 18) 


\subsection{Fios da ficção, fios da filosofia: a conclusão de uma leitura tramada}

O referido conto de Clarice Lispector é ambientado em uma escola cujos personagens são um professor inadaptado à vida e uma aluna sensível e desastrada ou inocentemente provocadora; sua perspectiva temporal permite à narradora-escritora buscar as origens da sua própria formação. Essas escolhas para o espaço, tempo, personagens e foco narrativo da história mais o uso de uma fábula que foi utilizada também por Benjamin permitem à autora a feitura de uma trama que, conforme parte da análise aqui proposta, reconfigura a perspectiva benjaminiana de transmissão da experiência de vida. De privilegiadamente oral, passa a ser escrita; antes destinada ao mais jovem, agora, no conto, é produzida por ele.

Em outras palavras, Clarice tece e entretece questões que foram suscitadas por Benjamin em uma ambientação narrativa que assenta aspectos aparentemente (ou isoladamente) inajustáveis na crítica do filósofo: é uma menina quem percebe o vazio angustiante de um adulto, menina que, além da sensibilidade, conta com o distanciamento da observação - ele é o seu professor, ele se expõe o tempo todo e não goza de qualquer autoridade ou influência familiar, ele é unicamente o seu professor; é uma menina (Sofia), tendo a inocência como sabedoria, quem continua por escrito (já que se tratava de uma aula de português) uma narrativa contada, com a qual, não sem muita perplexidade, aconselha um adulto; é uma menina, assim, quem toma a escrita como um ofício, conforme anos mais tarde rememora a escritora. Ou seja, enquanto Benjamin consagra a narrativa oral como meio de transmissão de experiência e sabedoria para o mais jovem, Clarice consagra um momento da narrativa escrita (oriunda de uma oral) como meio de transmissão de inocente sabedoria para o mais velho. Embora haja ponto de convergência com Benjamin, a saber, a identificação de um universo adulto moderno esvaziado, angustiado, empobrecido, o que se destaca no conto não é o olhar voltado para trás, para o fim da transmissão da experiência, tesouro íntimo, mas sim o olhar adiante, antecipador do porvir de tantas outras narrativas (“[...] escrevi a composição que o professor mandara, ponto 
de desenlace dessa história e começo de outras [...]") e, assim, de novas possibilidades de transmissão ${ }^{3}$.

Conforme se faz notar no próprio conto, a mesma escritora que aconselha é também leitora - ou receptora de conselhos. Assim, o conto é finalizado com duas observações de grande relevância que sintetizam uma harmonia possível entre os alcances da narrativa escrita e os da narrativa tal qual a preconizava Benjamin. Dito de outro modo, Clarice, no conto que tematiza a escrita narrativa, reconfigura a abordagem de Benjamin sobre a narrativa oral. Sofia, que arranhou de morte e arrancou os espinhos mortais do professor (LISPECTOR, 1999, p. 27), deixa-nos entrever a existência germinal de outras narrativas a serem por ela criadas, bem como o seu papel de leitora das criações de outrem:

[...] E foi assim que no grande parque do colégio lentamente comecei a aprender a ser amada, suportando o sacrifício de não merecer, apenas para suavizar a dor de quem não ama. Não, esse foi somente um dos motivos. É que os outros fazem outras histórias. Em algumas foi de meu coração que outras garras cheias de duro amor arrancaram a flecha farpada, e sem nojo de meu grito. ${ }^{4}$ (LISPECTOR, 1999, p. 28)

3 É mister destacar no próprio Benjamin outras possibilidades de transmissão da experiência, uma vez que o filósofo também suscitou a sabedoria infantil em seus escritos. Nas narrativas que compõem o Infância em Berlim por volta de 1900 há as mais variadas situações da infância rememoradas pelo adulto que, desse modo, no presente, também as faz legado para o porvir. É assim que em "A biblioteca do colégio", de modo semelhante ao que se passa em "Os desastres de Sofia", Benjamin rememora o fascínio infantil pelos livros e, diante disso, o diminuto papel do adulto-professor em sugerir-lhe leituras: "[...] finalmente chegava o momento em que, na mesma sala, até há pouco palco de minha humilhação, eu me revestia daquela plenitude de poder que cabe a Fausto quando lhe aparece o demônio. O que era, afinal, o professor que agora deixava seu estrado para vir recolher os livros e redistribuí-los, senão um demônio menor que devia renunciar a seu poder maléfico e pôr sua arte a serviço de meus desejos? E como malograva cada uma de suas tentativas de conduzir minha escolha com uma indicação! E que enorme frustração em seu ofício de pobre diabo, quando há muito tempo eu me encontrava num tapete mágico a caminho da tenda do último dos moicanos ou do acampamento de Konradin von Staufen" (BENJAMIN, 2009, p. 116).

4 Destaque nosso. 
Em tempo, este conto de Clarice guarda relações intertextuais com uma narrativa, justamente, do final do século XIX, período também abordado por Benjamin em suas reflexões sobre a Modernidade. Narrativa de autoria, segundo consta, de uma escritora que se consagrou enquanto tal depois dos 50 anos, ao escrever as histórias que, antes, contava para as netas (INFOPEDIA, 2013). Trata-se da Condessa de Ségur (1799 - 1874), reconhecida já no referido século como autora de obras-primas da literatura infantil, entre elas "Les Malheurs de Sophie", história que trata das inúmeras artimanhas de uma menina, Sofia, de 7 anos de idade.

\section{CONCLUSÃO}

A conclusão à qual por ora se chega é a de que, conforme se depreende do texto-conferência que responde por rara aparição teórica da escritora, o comprometimento literário de Clarice Lispector - fortemente referenciada como uma estrela singular na história da literatura brasileira com significativos pares na literatura universal - filia-se muito conscientemente à tradição literária brasileira moderna. E o faz com agudos talento e vocação responsáveis por girarem a roda da vanguarda, tal como a compreendeu a autora.

A vanguarda para Clarice conjuga com o movimento lírico nascendo no "eu profundo", como quis Mário de Andrade, e, portanto, correspondente às progressões do amadurecimento desse "eu". O conto "Os desastres de Sofia", que modernamente reinventa, enriquecendo-a, um tipo de "pobreza" advinda com a Modernidade, segundo Benjamin, exemplifica essas observações, ou esse movimento.

Enquanto Walter Benjamin, no início do século XX, em olhar voltado para trás, lamenta a progressiva extinção das narrativas orais, através das quais os mais velhos orientavam os mais jovens, Clarice Lispector, na década de 60, em olhar germinal voltado para frente, narra a auto-descoberta do ofício de escritora por parte de uma jovem que, em narração escrita, orienta um adulto e que, "virgem anunciada", descobre ser essa sua história o ponto de desenlace de muitas outras, por virem, à frente. 


\section{REFERÊNCIAS}

ANDRADE, Mário de. A Escrava que não é Isaura. Discurso sobre algumas tendências da poesia modernista. Rio de Janeiro: Nova Fronteira, 2010.

BENJAMIN, Walter. Obras escolhidas. Magia e Técnica, Arte e Política. São Paulo: Brasiliense, 2011.

BENJAMIN, Walter. Obras escolhidas II. Rua de Mão Única. São Paulo: Brasiliense, 2009.

INFOPEDIA. Disponível em <http://www.infopedia.pt/\$condessa-de-segur $>$. Acesso em: 4 mar. 2013.

LISPECTOR, Clarice. A Legião Estrangeira. Rio de Janeiro: Rocco, 1999.

LISPECTOR, Clarice. A Paixão segundo GH. Rio de Janeiro: Rocco, 1998.

LISPECTOR, Clarice. Sobre o Conceito de Vanguarda. Remate de Males, Campinas, n.12, 1992.

LISPECTOR, Clarice. Outros Escritos. MONTERO, Teresa e MANZO, Lícia (Org.). Rio de Janeiro: Rocco, 2005.

SOUSA, Carlos Mendes de. Pensar a língua: Clarice Lispector e a literatura brasileira. Agulha- revista de cultura, Fortaleza - São Paulo, n. 31, 2002. 